\title{
Saláo de poses: notas para uma teoria da moda em Machado de Assis
}

Victor da Rosa

UFSC

\begin{abstract}
Resumo
Este artigo procura abordar algumas das maneiras pelas quais a ficção de Machado de Assis tratou a questão da moda. Seja por meio do estudo dos costumes e dos trajes, sobretudo das alteraçóes de suas formas, e seja ainda por uma relação específica que seus relatos estabelecem com o tempo, o escritor não apenas esteve atento ao problema da moda, como também fez dele motivo de várias das suas criaçóes. $\mathrm{O}$ artigo desenvolve tal abordagem a partir de três perspectivas críticas: a de uma tradição que discutiu o problema das mercadorias no século XIX, sobretudo com Balzac e Walter Benjamin; por meio de um diálogo com uma espécie de "metafísica da aparência" mais contemporânea, que surge aqui por meio dos trabalhos de Boris Groys e Emanuele Coccia; e finalmente em diálogo com alguma crítica machadiana - de Roberto Schwarz e José Miguel Wisnik aos mais recentes Idelber Avelar e Ana Luiza Andrade.
\end{abstract}

Palavras-chave: Machado de Assis; Moda; Roupa; Tempo; Pose.

\begin{abstract}
This article intends to address some of the ways in which Machado de Assis' fiction addressed the issue of fashion. Whether it is through the study of costumes and clothes, especially of changes in their forms, or even through a specific relationship that his narratives establish over time, the writer not only was attentive to the problem of fashion, but also made of it the theme for several of his writings. The article develops this approach from three critical perspectives: that of a tradition that discussed the problem of commodities in the nineteenth century, especially Balzac and Walter Benjamin; by means of a dialogue with a more contemporary sort of "metaphysics of appearance," which appears here through the works of Boris Groys and Emanuele Coccia; and finally, through the dialogue with some Machadian critics, from Roberto Schwarz and José Miguel Wisnik to the more recent Idelber Avelar and Ana Luiza Andrade.
\end{abstract}

Keywords: Machado de Assis; Fashion; Clothing; Time; Pose. 
1 ANDRADE, Ana Luiza. Transportes pelo olhar de Machado de Assis, 1999, p. 241-243.

2 ASSIS, Machado de. "Um homem célebre”, 2008, p. 464.

3 WISNIK, José Miguel. Machado maxixe, 2008, p. 9.

4 Ibidem, p. 15.

5 Ibidem, p. 13.

\section{Introduçáo}

Em ensaio sobre Machado de Assis, Ana Luiza Andrade afirma que a crônica, à medida que recorta "o talhe passageiro da reprodutibilidade", é um gênero que "parece estar sempre na última moda". Para a crítica, Machado registra a moda de duas maneiras: por meio das "mudanças industriais, da substituição dos nomes dos remédios às próprias reformas político-econômicas", a exemplo do caso da tabuleta, relatado em Esaú e Jacó, quando o dono da "Confeitaria do Império", com a queda do regime monárquico, não sabe mais que nome dar a seu estabelecimento; e por meio das "estéticas dos trajes", sobretudo no estudo de suas alteraçôes. A crítica lembra, por exemplo, de uma crônica em que Machado relata as mudanças da altura dos chapéus, tema que surge depois no conto "Capítulo dos chapéus". Assim como a moda, a crônica "imita a dobra de sua origem industrial na natural, entrando nos ciclos repetitivos do eterno retorno de inovaçóes.” ${ }^{1}$

Machado lida com diversos aspectos do que podemos chamar de moda, e a proposta deste artigo é investigá-los. Por um lado, temos descriçóes da "gravata de cetim preta" de José Dias e das tranças no cabelo de Capitu como elementos que eram a "moda do tempo", mas o significante reaparece quando o assunto é não o traje, mas a arte, no caso a música, referindo-se às polcas de Pestana, do clássico "Um homem célebre" - polcas que eram então "cançôes da moda". ${ }^{2}$

Fazer parte da moda é motivo de vergonha para Pestana, embora ele seja despertado pelo "comichão da publicidade". A celebridade é incontornável em sua vida, e continuará sendo depois de sua morte, se tudo der certo com a polca em homenagem à subida dos liberais ao poder, prometida ao editor no último diálogo. Embora as discussóes em torno do conto encarem os dilemas musicais do personagem como o seu assunto central, sobretudo a partir da leitura de José Miguel Wisnik, o título indica que a narrativa trata primeiro de celebridade e fama. Em Machado maxixe, Wisnik diz que "Um homem célebre" realiza uma "crítica pioneira da cultura de massas", ${ }^{3}$ e isso porque tanto o conto quanto "O machete", texto anterior de Machado, promoveriam "a identificaçáo positiva com o mundo representado pelo violoncelo, em clara oposição ao mundo representado pelo cavaquinho". ${ }^{4}$ Wisnik parte de uma fronteira bem definida entre "música séria" (a expressão é sua, assim como o itálico) e "música de atrativo popular", e vincula a posição de Machado com a de quem afirma "a superioridade moral, intelectual e espiritual do violoncelista sobre o cavaquinista”, descrito como “"um espírito medíocre', avesso a qualquer ideia, com mais nervos do que alma, e cuja perícia se combina com exibicionismo puro". 5

Como notou Idelber Avelar, a hipótese é problemática porque parece ignorar o traço mais marcante da literatura de Machado: a sátira, a ironia. Avelar argumenta que "Se é correto que se vê n"'O machete' o 'pressuposto 
implícito da superioridade da cultura letrada, isenta dos apelos fáceis da música vulgar', em meu entender a identificação com o mundo da alta cultura estaria aqui atravessada pela ironia." Embora reconheça que Machado possa cultivar alguma nostalgia "do tempo em que a arte erudita - metonimizada pelo violoncelo - ainda não havia perdido seu capital cultural", Avelar defende que tal identificação é "menos clara e automática do que nos faria crer Wisnik", pois no caso de "O machete", sobretudo, "o narrador visivelmente toma distância irônica e debochada ante o personagem de Inácio Ramos, o corno", que é uma figura "deslocada de seu tempo não por ser subversiva ou intempestiva, mas por ser anacrônica”, 7 e não é muito diferente o que acontece com Pestana.

O que interessa para este artigo é a posição em que Inácio é posto, assim como Pestana, segundo a descrição de Avelar: deslocado do tempo, fora de moda. O crítico afirma que "O machete", mas também "Um homem célebre”, mais que pressupor "a superioridade 'essencial' de uma cultura sobre a outra, [...] faz a crônica de uma queda e de uma transição". O gênero maxixe seria o nome de algo "que ainda náo podia ser nomeado." ${ }^{8}$

Boris Groys, em reflexão sobre o novo, dedica um belíssimo fragmento à moda: "Le nouveau et la mode". Groys argumenta neste fragmento que, apesar das condenaçóes que a moda vem sofrendo desde a modernidade, ela também possui um traço revolucionário: “[...] a moda é radicalmente anti-utópica e anti-totalitária, pois que a sua incessante mudança demonstra que o futuro não é previsível, que ele não pode escapar da mudança histórica, e não há verdade universal que possa ser determinada em sua integralidade." Para Groys, a condenação que se faz à moda parte da crença em uma verdade universal, capaz de determinar o presente e o futuro em sua integralidade, ou mesmo da crença de que o dever do pensamento é se preservar da mudança histórica. A moda, pelo contrário, devido a seu caráter transitório, seria um meio através do qual é possível se liberar do poder do passado: “[...] o novo confere ao autor individual a possibilidade de afirmar a sua própria vida como um valor no tempo histórico e de se libertar então do poder do passado." 10

Em "Um homem célebre", Machado explora os dilemas que a moda impôe ao poder da tradição. Se o conto pode ser lido em chave histórica, por meio dos dilemas que envolvem diferentes culturas musicais no século XIX, ele explora também outro conflito: entre novo e velho, crise e tradição. Nele, a polca é vinculada a uma "alegria nova", que contagia o ambiente assim que os primeiros compassos de Não bula comigo, nhonhô são ouvidos. Mas depois Pestana se depara com uma "Casa velha, escada velha, um preto velho que o servia", sendo a "casa velha" uma herança recebida, assim como "os velhos trastes, ainda do tempo de Pedro I", e as liçôes de "música e latim”
6 AVELAR, Idelber. "Entre o violoncelo e o cavaquinho: música e sujeito popular em Machado de Assis". Estudos de literatura brasileira contemporânea, 2011, p. 184.

7 Ibidem, p. 179.

8 Ibidem, p. 185.

9 GROYS, Boris. Du nouveau: essai d'économie culturelle, 1995 , p. 47.

10 Ibidem, p. 50. 
11 ASSIS, Machado de. "Um homem célebre”, 2008, p. 465-466.

12 Ibidem, p. 468.

13 Ibidem, p. 467.

14 Ibidem, p. 466.

15 ASSIS, Machado de. "Uma visita de Alcebíades”, 2008, p. 329. também são heranças. Os ensinamentos musicais são sugeridos pela galeria de retratos, "uns dez retratos", "alguns gravados, outros litografados, todos mal encaixilhados", que Pestana conserva na "sala dos fundos", a maioria de compositores clássicos, as "velhas fontes". Ao lembrar deles, o narrador ainda faz alusão a "velhas obras clássicas". ${ }^{11}$ Tudo que se refere ao universo da música clássica vem acompanhado da ideia de "velhice", que significa herança e tradição, mas também repetição, desespero e morte. Até a memória é definida como "um beco escuro, velha cidade de traiçôes". ${ }^{12}$

Por outro lado, ao se referir às polcas, o conto cria vínculos com a novidade. A polca é descrita como algo da moda, chegando a esta redundância reveladora: "a nova polca da moda". ${ }^{13}$ A roda da história anda depressa e é preciso ter uma nova polca a cada vinte dias, daí a expressão "nova moda". Para compor uma polca era necessário então "esquecer os retratos que pendiam gravemente na parede". A música popular nascia "sem os vãos esforços da véspera, sem exasperação, sem nada pedir ao céu, sem interrogar os olhos de Mozart". Se ao compor uma peça clássica a sensação é de cansaço, desânimo e morte, a composição de polcas significa "Vida, graça e novidade", que "escorriam-lhe da alma como de uma fonte perene." ${ }^{14}$ Os títulos das polcas, por isso, estão em sintonia com o tempo, fazendo "alusão a algum sucesso do dia”, como $A$ lei de 28 de setembro, mesmo que não queira significar nada, pois o importante é "popularizar-se logo". Machado mobiliza todo um léxico novo na tentativa de expressar este "comichão" que surge de mãos dadas com a moda: publicidade, fama, celebridade, popularidade, sucesso.

\section{Sistema de moda}

Há outro conto de Machado que, também em chave irônica, e dessa vez fantástica, explora o mesmo deslocamento do sujeito em relação a seu tempo, agora por meio do uso do traje. É o conto "Uma visita de Alcibíades", cujo mote consiste na vinda do personagem grego, que sai das páginas de Plutarco, para a capital brasileira em pleno século XIX, após o desembargador perguntar a si mesmo: "Que impressão daria ao ilustre ateniense o nosso vestuário moderno?". O ateniense acode ao chamado e, pouco depois, aparece na sala, encostado na parede, "mas não era a sombra impalpável que eu cuidara ter evocado [...]; era o próprio Alcibíades, carne e osso, vero homem, grego autêntico" - e, o mais importante, "trajado à antiga". ${ }^{15}$

O conto se desenvolve por meio do conflito entre traje antigo e moderno, assim que o desembargador revela a vontade de ir ao baile. "Um baile? Que coisa é um baile?", questiona Alcibíades, que espera "dançar a pírrica". A emenda do outro é uma definição da moda que lembra a teoria de Groys: "Não, a pírrica já lá vai. Cada século, meu caro Alcibíades, muda de danças 
como muda de ideias. Nós já não dançamos as mesmas coisas do século passado; provavelmente o século XX não dançará as deste. A pírrica foi-se”, diz o desembargador. ${ }^{16}$ Não é possível dançar a pírrica porque ela não faz parte da moda, assim como Alcibíades com seu traje à antiga não faz. O ilustre ateniense é tido então como um louco, por conta do traje e da pírrica, e por isso não pode comparecer ao baile: "não o admitiriam, com aquele traje; pareceria doido; salvo se ele queria ir lá representar alguma comédia de Aristófanes." 17

Machado descreve aí um sistema de moda. Nas palavras de Roland Barthes, trata-se de um sistema que "justifica, obriga, proíbe e tolera". ${ }^{18}$ Em "História e sociologia do vestuário", Barthes reclama que as análises da moda não levam em conta as "correlaçóes normativas" que a definem, ou seja, "as correlaçóes [...] que regulam a disposição das peças num usuário concreto, captado em sua natureza social, histórica." ${ }^{19}$ Para o crítico, a moda é um valor, e é assim que deve ser pensada: em termos de instituição, e não como formas estéticas ou por meio de motivaçôes psicológicas. O historiador, o sociólogo e o ficcionista "não têm de estudar apenas gostos e comodidades; precisam recensear, coordenar e explicar regras de disposição ou uso, imposições e proibições, tolerâncias e transgressóes", enfim, devem recensear condições e valores. ${ }^{20}$

Em outro conto de Machado, "Ernesto de Tal”, que também explora de maneira hábil as imposiçóes e proibiçóes que a moda impóe, o registro do sistema de moda se dá em chave mais realista. Tal como Alcibíades, Ernesto não pode frequentar um baile, mas agora porque, sendo pobre, não possui condiçóes para adquirir o traje adequado, uma casaca. Dessa vez o conflito evolui sob a lente da separação de classes, não mais da separação do tempo.

No conto, ficamos sabendo que Ernesto está do lado de fora de uma festa, acompanhado apenas pela "cólera que lhe murmura no coração" e pelo desejo de encontrar a moça por quem "anda simplesmente apaixonado” ${ }^{21}$ Ernesto não pode comparecer à festa porque náo possui a tal casaca, afinal junto ao convite do Sr. Vieira vem também uma exigência, tida como "absurda" pelo narrador, mas definitiva: "Ah! esquecia-me avisá-lo de uma coisa - disse Vieira que já havia dado alguns passos -; como vai o subdelegado, que além disso é comendador, eu desejava que todos os meus convidados aparecessem de casaca. Sacrifique-se à casaca, sim?”. Ernesto responde que se sacrifica "com muito gosto", mas fica "pálido como um defunto", pois "não possuía uma só casaca nova nem velha". ${ }^{22} \mathrm{O}$ conto investiga não só o caráter normativo da moda, mas também o constrangimento que tal normatividade causa em quem não faz parte dela, assim como o ridículo da exigência. Por meio de uma simples casaca, o conto traça uma linha que separa dentro e fora (da festa e da moda). Se Ernesto é praticamente o único
16 Ibidem, p. 330.

17 Ibidem, p. 331.

18 BARTHES, Roland. "História e sociologia do vestuário”, 2005 , p. 266.

19 Ibidem, p. 266.

20 Ibidem, p. 266.

21 ASSIS, Machado de. "Ernesto de Tal”, 2008, p. 187.

22 Ibidem, p. 187. 
23 Ibidem, p. 188.

24 ASSIS, Machado de. "Uma visita de Alcebíades”, 2008, p. 331.

25 Ibidem, p. 333.

26 Ibidem, p. 334. que não possui o traje, é por isso que não possui um sobrenome, fato que é mencionado de passagem pelo narrador: "Ernesto de Tal (não estou autorizado para dizer o nome todo)”. Por que não estaria?

A situação de Ernesto, embora descrita como "gravíssima" e "desgraçada", não é definitiva, e três ideias ocorrem ao personagem: "encomendar, por qualquer preço, uma casaca para a noite seguinte; comprá-la a crédito; pedi-la a um amigo", mas as duas primeiras são descartadas porque "Ernesto não tinha dinheiro nem crédito tão alto". Já os amigos não podem socorrê-lo por motivos diversos que, da forma como são apresentados, formam uma espécie de sociologia da casaca: o primeiro tinha um casamento; o segundo um baile; a casaca do terceiro estava avariada; o quarto havia emprestado a sua; o quinto não emprestava de jeito nenhum; e o sexto, como o próprio Ernesto, não possuía uma. Para aumentar "a requintada crueldade com que o destino tratava este moço", ao voltar para casa, Ernesto cruza com três enterros, sendo que em dois deles havia "muitos carros, cujos ocupantes iam todos de casaca". ${ }^{23}$

\section{Na moda ou morte}

Nos contos de Machado é comum que as noçôes de moda e morte andem juntas. No caso de "Uma visita de Alcibíades", a exclusão do personagem dos códigos da moda o leva à morte. Momentos antes de sua morte, Alcibíades indica seu desejo de vestir-se "à maneira do século", e pede ao desembargador que se vista primeiro, "para eu aprender e imitar-te depois". Os valores do mundo grego são coisa do passado, não passam de "restos" que "um ou outro prosador alude [...], ao passo que a ciência reduziu todo o Olimpo a uma simbólica. Morto, tudo morto”, inclusive Alcibíades, que morre no desfecho do conto. ${ }^{24}$

Apesar do desejo de imitação, Alcibíades ridiculariza o desembargador por conta dos seus "canudos de pano", no caso as calças, e age com assombro ao confundir o nó na gravata com uma tentativa de suicídio. O personagem ainda desaprova as cores do século, que julga mortas e tristes, "cor de noite", concluindo que o mundo devia andar "imensamente melancólico", e desaprova também a casaca que, ao contrário das calças, é um "par de canudos abertos". ${ }^{25}$ Ele não pode entender o traje do desembargador porque vive em um "domínio da arte ideal, desinteressada, superior aos tempos que passam e aos homens que os acompanham". Já o homem moderno, para quem "a arte de vestir é outra coisa", sabe que o belo, por mais que pareça "absurdo ou desgracioso", só pode ser "belo à nossa maneira, que não andamos a ouvir na rua os rapsodos recitando os seus versos." 26 Daí o conto ser marcado pela falta de identificação entre um personagem e outro: o conflito se desen- 
volve não por meio das ideias, mas do costume e da roupa. Em seu verbete sobre moda, nas Passagens, Benjamin defende que o processo de consumo do vestuário - e não mais da arte - é que cria "o protótipo do homem e da mulher modernos... Imitam-se os manequins, e a alma se faz à imagem do corpo" ${ }^{27}$ Seja como for, no conto de Machado, o processo de imitação falha, e a expulsão do personagem grego do reino da moda o leva à morte, ou de volta ao mundo grego.

Em “Um homem célebre”, moda e morte também são apresentadas em par, e em contraste. O dilema de Pestana entre novo e velho é explorado por meio do imaginário das duas mulheres do conto, e o imaginário da morte ronda a vida de uma delas. A primeira é Sinhazinha Mota, que praticamente traz a moda no nome, uma jovem de vinte anos que reconhece o músico em um sarau, pede para que ele toque Náo bula comigo, nhonhô ao piano, e adormece pensando nele, "famoso autor de tantas polcas amadas". Ou seja, uma figura típica do mundo do entretenimento. Mas Pestana acaba casando com Maria, uma viúva nem bonita e nem feia, na esperança de que o celibato fosse "a causa da [sua] esterilidade e do transvio". ${ }^{28}$ Maria é escolhida porque possui duas "qualidades": é cantora clássica e tísica, sendo que a segunda prenda vai na conta da ironia do tio de Sinhazinha Mota, que dá a notícia do casamento à sobrinha. Sinhazinha é a mulher moderna, atenta ao mundo do entretenimento, enquanto Maria é uma romântica, destinada então a morrer.

Se em "Uma visita de Alcibíades" o personagem grego sucumbe a uma morte patética após uma espécie de choque com a moda do século XIX, em "Um homem célebre" o dilema de Pestana gira em torno das noçôes incompatíveis de morte e moda.

Benjamin, ao lembrar de um fragmento recortado de um jornal alemão de 1925, que definia a moda pela ideia de extremos, anota que "seus máximos extremos" são "a frivolidade e a morte" ${ }^{29}$ Em outra anotação, o filósofo recorre à noção de morte, mas não para definir a moda, e sim para expor sua outra face: "a moda nunca foi outra coisa senão a paródia do cadáver colorido, provocação da morte pela mulher, amargo diálogo sussurrado com a putrefação entre gargalhadas estridentes e falsas. Isso é a moda”, escreve. É por mudar tão rapidamente, e por "sua extraordinária capacidade de antecipação", que a moda "faz cócegas na morte e já é outra, uma nova, quando a morte a procura com os olhos para bater nela. Durante um século, a moda nada ficou devendo à morte." 30

Benjamin dá o nome de "temporalidade do inferno" ao caráter provisório do tempo na moda. A partir de Balzac, para quem "a moda é a procura sempre vã, muitas vezes ridícula, às vezes perigosa, de uma beleza superior
27 BENJAMIN, Walter. Passagens, 2006, p. 116.

28 ASSIS, Machado de. "Um homem célebre”, 2008, p. 468.

29 BENJAMIN, Walter. Passagens, 2006, p. 108.

30 Ibidem, p. 102. 
31 Ibidem, p. 104-105.

32 MORETTI, Franco. "Homo Palpitans: os romances de Balzac e a personalidade urbana”, 2007 , p. 138.

33 ASSIS, Machado de. "O espelho", 2008, p. 323.

34 BENJAMIN, Walter. Passagens, 2006, p. 103.

35 Ibidem, p. 107. ideal", o filósofo argumenta que se trata de uma temporalidade que "não quer conhecer a morte", e por isso muda "como a rapidez do trânsito e a velocidade da transmissão de notícias", visando eliminar "toda interrupção, todo fim abrupto". ${ }^{31}$

Franco Moretti, em ensaio sobre Balzac, diz que a moda não é exatamente uma pista (um meio que apontaria para um fim) e sim um "signo tautológico". Ao lembrar de Simmel, para quem "um objeto está na moda porque está na moda", Moretti acrescenta: "um objeto está na moda porque está na moda agora." ${ }^{2}$ A moda é filha do tempo, quer dizer: "Cada século [...] muda de danças como muda de ideias". Em "O espelho", quando o narrador procura explicar o que é a "alma exterior", além de afirmar que ela pode se manifestar em "um simples botão de camisa", em um par de botas e na própria polca, o personagem explica que a condição da alma exterior "não é sempre a mesma", e que pode mudar até "cinco, seis vezes por ano":

\footnotetext{
[a alma exterior] muda de natureza e de estado. [...] Há cavalheiros, por exemplo, cuja alma exterior, nos primeiros anos, foi um chocalho ou um cavalinho de pau, e mais tarde uma provedoria de irmandade, suponhamos. Pela minha parte, conheço uma senhora - na verdade, gentilíssima - que muda de alma exterior cinco, seis vezes por ano. Durante a estação lírica é a ópera; cessando a estação, a alma exterior substitui-se por outra: um concerto, um baile do Cassino, a rua do Ouvidor, Petrópolis... ${ }^{33}$
}

Além da relação infernal com o tempo, o verbete de Benjamin explora outra consequência deste "amargo diálogo" entre moda e morte. O filósofo argumenta que o "verdadeiro espetáculo dialético da moda" consiste na formação daquilo que é "totalmente novo" quando "emerge entre as coisas mais antigas, mais passadas, mais habituais". É também por meio desta relação (ou deste espetáculo) que "o reino nebuloso, silencioso e impenetrável da moda" é capaz de captar "toda a energia onírica" de uma sociedade árida e pouco imaginativa, e por isso a moda seria a "eterna suplente do Surrealismo" ${ }^{34} \mathrm{O}$ tom de Benjamin é machadiano, assim como a concepção inconstante do tempo histórico, que Machado explora náo só nos contos, mas também nas Memórias póstumas de Brás Cubas, em que a condição narrativa póstuma e o "amor da nomeada" se associam. Quanto a isso, Machado entendeu não apenas a força da moda em captar uma energia associada ao sonho, mas o escritor parece ter entendido também que tal associação nasce de uma relação que a moda estabelece com o inorgânico. "Toda moda", arremata Benjamin em outro belíssimo fragmento, "está em conflito com o orgânico. Cada uma delas tenta acasalar o corpo vivo com o mundo inorgânico. A moda defende os direitos do cadáver sobre o ser vivo. $\mathrm{O}$ fetichismo que subjaz ao sex appeeal do inorgânico é seu nervo vital." 35 


\section{4. "O eterno à novidade"}

As Memórias póstumas buscam sacrificar "o eterno à novidade", diz Roberto Schwarz. Por isso seus capítulos são curtos, e muitas vezes o narrador sugere que sejam pulados, pois o que interessa é o que vem do futuro, mesmo que náo venha nada. Se pensarmos na maneira como Benjamin diferencia a escultura, feita em "um só bloco", e o cinema, "arte montável", temos uma pista da afinidade que o romance possui com as novas técnicas. ${ }^{36}$ Como afirma Schwarz, se "o escândalo das Memórias está em sujeitar a civilização moderna à volubilidade", ${ }^{37}$ tal efeito é construído por meio de uma "ordem tátil", ou seja, "baseia-se na mudança de lugares e ângulos, que golpeiam intermitentemente o espectador”. É com estas últimas palavras que Benjamin descreve o dadaísmo e o cinema, embora pareça se referir ao romance machadiano, que vieram para libertar a relação entre "choque físico" e "choque moral", unificando "os dois efeitos de choque, num nível mais alto". ${ }^{38}$

Outro aspecto das Memórias que se associa à moda diz respeito ao estilo “mais galante e mais novo" da escrita de Brás. Schwarz chega a afirmar que a preocupação com tal estilo é uma preocupação "com a moda", e talvez seja por isso que o crítico use tantas metáforas ligadas ao traje para explicar o estilo do romance. Schwarz enfatiza que a comparação das Memórias com o Pentateuco, que "entra a título de coisa antiga", tem a função justamente de marcar uma oposição entre velho e novo: "É como se a condução da frase dissesse que no frigir dos ovos o método e as consideraçóes do autor não se completam e são moda pura." ${ }^{39}$ Se o personagem escreve como se estivesse "diante do espelho", e se suas feiçôes - as constantes mudanças no rumo de sua prosa - são como roupas que "constantemente ele veste e desveste", entâo o romance é um "desfile de encarnaçôes". ${ }^{40}$ Em suma, certa noção de moda é evocada pelo crítico para explicar a escrita de Brás porque ambas são terrenos movediços, indefinidos, lugares de artifícios.

A volubilidade é o "princípio formal" do livro, diz Schwarz, e este princípio possui uma espécie de ciclo, que também vai e volta no decorrer da prosa. O crítico defende que tal ciclo possui três movimentos. $\mathrm{O}$ primeiro consiste no "gosto pela novidade"; o segundo diz respeito ao "abandono seco do modo-de-ser prévio"; e, na junção de ambos, o efeito é de "inferiorização do leitor, desnorteado e inevitavelmente em sintonia com a figura 'velha', anterior, que acaba de cair." ${ }^{41}$ Para Schwarz, a repetição do ciclo faz da "novidade promissora" uma promessa cada vez mais descartável, pois as ideias, as posturas e as convicçóes, na ausência de conteúdo, entram no jogo do "consumo acelerado". 42

Este é o próprio ciclo da moda, que por ser volúvel "zomba da morte". Brás é um personagem que "acompanha os tempos", que deseja estar
36 BENJAMIN, Walter. "A obra de arte na era de sua reprodutibilidade técnica”, 1994, p. 176.

37 SCHWARZ, Roberto. Um mestre na periferia do capitalismo, 1990, p. 56.

38 BENJAMIN, Walter. "A obra de arte na era de sua reprodutibilidade técnica”, 1994, p. 176.

39 SCHWARZ, Roberto. Um mestre na periferia do capitalismo, 1990 , p. 27.

40 Ibidem, p. 22-24.

41 Ibidem, p. 49.

42 Ibidem, p. 40. 
43 Ibidem, p. 63.

44 COCCIA, Emanuele. A vida sensivel, 2010, p. 22.

45 ASSIS, Machado de. Esaú e Jacó, 2008, p. 1161.

46 COCCIA, Emanuele. A vida sensivel, 2010, p. 86.

47 Ibidem, p. 86.

48 CARVALHO, Flávio de. $A$ moda e o novo homem, 2010, p. 16.

49 COCCIA, Emanuele. A vida sensivel, 2010, p. 88.

50 Ibidem, p. 89.

51 Ibidem, p. 90. na moda: “[...] é romântico da mesma forma perfunctória como é liberal, cientista, filósofo, política ou poeta: para acompanhar os tempos, segundo as prerrogativas da própria posição e sem a disciplina exigível”. Quanto a isso, segundo a classificação de Balzac, o personagem machadiano faz parte daquela categoria do "homem que nada faz", da qual decorre a "a vida elegante”. Schwarz chega a associar a coincidência, no percurso de Brás Cubas, entre a falta da relaçáo do personagem com o trabalho e a ausência de "qualquer forma de projeto consistente". ${ }^{43}$

\section{Metafísica do chapéu}

Emanuele Coccia define imagem como uma "forma fora do próprio lugar" ${ }^{44}$ É esta a sensação que o alferes tem quando vê sua alma recolhida no espelho, mas não só. Se na ficção machadiana predomina o mundo onde "a aparência era mui diversa do coração", ${ }^{45}$ como diz o conselheiro Aires em Esaú e Jacó, temos outra pista para pensar a relação que a ficção de Machado estabelece com a moda. Em sua tentativa de definir os sujeitos como "aqueles que aparecem”, Coccia diz que não é apenas "a interiorização da imagem no espelho que permite que nos tornemos um eu, mas sim qualquer assunção de uma imagem que seja capaz de nos fazer aparecer de um certo modo." ${ }^{46}$ A moda é um conceito central para entender a teoria de Coccia - e a ficção de Machado - porque ela se apresenta como um "processo de identificação realizado com instrumentos não psicológicos”. ${ }^{47}$

Flávio de Carvalho argumenta também que a roupa é o que mais exerce "influência sobre o homem" porque é aquilo que "está mais perto do seu corpo e seu corpo continua sempre sendo a parte do mundo que mais interessa". ${ }^{48}$ E Coccia diz que "nosso ser no mundo é desenhado [...] pela capacidade de assumir uma parcela de mundo como roupa: segundo corpo, segunda natureza mais próxima de nossa alma do que nosso próprio corpo anatômico." ${ }^{49}$ Por isso a roupa não se opõe ao corpo, é uma espécie de segundo corpo que, no entanto, possui características próprias, pois se trata de um corpo que "vive apenas como imagem e que transforma nosso próprio corpo anatômico em um meio." ${ }^{50}$ É como se o sujeito fosse definido por duas camadas, bios e ethos, que não se separam, mas que não devem se confundir, afinal corpo anatômico e roupa seriam dois polos de uma mesma realidade (o indivíduo), que não poderá ser definido por apenas um desses dois elementos. "Graças ao primeiro, o homem é capaz de vida, graças ao segundo, a vida anônima se individualiza. O primeiro é feito de carne, enquanto o segundo, pelo contrário, serve só para transformar o sujeito em imagem”, argumenta o filósofo. ${ }^{51}$

No "Capítulo dos chapéus", Conrado Seabra defende que a escolha de 
uma roupa, no caso o seu chapéu baixo, "não é uma ação indiferente", mas "regida por um princípio metafísico". A teoria é apresentada como se Seabra debochasse da esposa, e ele apresenta seus argumentos com tal "ironia e desdém, que a pobre dama sentiu-se humilhada", mas nem por isso devemos deixar de levar a teoria em conta, afinal seu "princípio metafísico" também associa bios e ethos, sendo o ethos um prolongamento da bios: "o chapéu é a integração do homem - diz Seabra - um prolongamento da cabeça, um complemento decretado ab eterno; ninguém o pode trocar sem mutilação", e vai longe: "Quem sabe? Pode ser até que nem mesmo o chapéu seja complemento do homem, mas o homem do chapéu." 52 Trocar o chapéu baixo por um alto, como quer a mulher - na verdade por influência do pai, que é um homem de "costume antigo", "aferrado aos hábitos" e "ralado de saudades do tempo em que os empregados iam de casaca para as suas repartiçôes" -, seria como perder ou mutilar parte do próprio corpo.

Ao tocar no problema da roupa, Coccia se refere à ideia de "encarnação" - a "roupa dos homens" nada mais seria do que "a vida dos viventes [que] se materializa em um sensível imediatamente encarnado no próprio corpo." ${ }_{33}$ Uma roupa seria então, antes de tudo, um corpo. Não se trata de recorrer à moda "a fim de encontrar uma forma de relação especial da temporalidade ou de captar a relação que liga o indivíduo à sociedade e aos seus códigos", mas para compreender "o que significa o fato de portar roupas e vesti-las" ${ }^{54}$ Da mesma forma que Machado, Coccia entende que a moda é a possibilidade de uma experiência nova dos sujeitos com os seus corpos, pois vestir-se significa "completar nosso corpo", "acrescentar-lhe uma consistência”, cujo "único objetivo é nos fazer aparecer". ${ }^{5}$

Balzac, por sua vez, conclui o texto "Sobre o sentimento da vida elegante" argumentando que "um tratado da vida elegante, reunião dos princípios incomutáveis que devem dirigir a manifestação de nosso pensamento para a vida exterior, é, de certo modo, a metafísica das coisas". A moda constrói um sistema que, na visão do romancista, funciona como "expressão da sociedade", já que o traje é o mais "enérgico de todos os símbolos", e por isso a revolução foi também uma questão de moda, "um debate entre a seda e o pano". ${ }^{56}$ Balzac foi não apenas o primeiro escritor que levou a moda a sério, mas também alguém que começou a pensar a moda como um sistema. Em sua reflexão sobre a gravata, o escritor chega a argumentar que "a gravata é o homem", pois é "através dela que o homem se revela e se manifesta." ${ }^{57} \mathrm{O}$ dilema do "Capítulo dos chapéus" surge porque o chapéu baixo de Seabra não possui a solenidade ou a gravidade exigida de um homem público, e é então avaliado pelo pai da esposa como "torpe", uma "abominação das abominaçôes". Trata-se de uma questão de "elegância" e, portanto, merece uma resposta, se quisermos pensar com Balzac, em termos metafísicos, que é a resposta que Seabra dá à esposa.
52 ASSIS, Machado de. "Capítulo dos chapéus”, 2008, p. 378.

53 COCCIA, Emanuele. A vida sensivel, 2010, p. 43.

54 Ibidem, p. 81.

55 Ibidem, p. 83-84.

56 BALZAC, Honoré de. "Sobre o sentimento da vida elegante", 2009, p. 57.

57 Ibidem, p. 12. 
58 ASSIS, Machado de. "Capítulo dos chapéus”, 2008, p. 381-382.

59 ANDRADE, Ana Luiza. Transportes pelo olhar de Machado de Assis, 1999, p. 246.

60 COCCIA, Emanuele. A vida sensivel, 2010, p. 88.

61 ASSIS, Machado de. "Capítulo dos chapéus”, 2008, p. 384.

62 BENJAMIN, Walter. "A obra de arte na era de sua reprodutibilidade técnica”, 1994, p. 170.

63 COCCIA, Emanuele. A vida sensivel, 2010, p. 72.
Daí na sequência do conto a esposa passar a ver só chapéus, e não mais homens: ao passear com uma amiga na rua do Ouvidor, "alguns chapéus masculinos começaram a fitá-las". Agora é como se fosse o homem o complemento do chapéu, e não o contrário, sendo que o número de chapéus se multiplica: “[...] duas ou três vezes [Mariana] chegou a levantar-se e ir à janela; mas os chapéus eram tantos e tão curiosos, que ela voltava a sentar-se", ${ }^{58}$ ou seja, o conto reproduz a máxima de Coccia segunda a qual viver significa aparecer. Ana Luiza Andrade argumenta, após lembrar da variedade de chapéus que aparece na gravura de Grandville, "bem similar às imagens-pensamento de Machado", que em sua ficção a moda muitas vezes faz a função de eliminar a figura humana, mimetizando o mundo inorgânico. ${ }^{59}$ No conto, a relação entre os sujeitos passa a ser definida pelos chapéus, e a roupa "não deixa de se tornar a nossa segunda pele. [...] Nosso primeiro ser no mundo é atualizado por nossas roupas: que estamos lançados no mundo significa apenas que podemos nos vestir." 60

"Capítulo dos chapéus" é um conto da era da reprodutibilidade técnica, afinal os chapéus se multiplicam, e este é um dos pesadelos da personagem. Primeiro é o chapéu do marido que aparece como motivo de reflexão; depois o de Viçoso, namorado antigo da personagem, o tal chapéu que "trazia uma linda gravata"; e que vem acompanhado por "alguns chapéus masculinos", verdadeiros "demônios que sucediam-se como num caleidoscópio"; sendo que os chapéus passam a ser "tantos e táo curiosos, que ela voltava a sentar-se." ${ }^{61}$ Eis aí outro "princípio metafísico" da moda: ela abre o reino do inumerável. Para Coccia, a moda deve ser pensada como a própria "fertilidade" da imagem. Já Benjamin tratava o declínio da aura como "a necessidade de possuir o objeto, de táo perto quanto possível, na imagem, ou antes, na sua cópia, na sua reproduçáo", ou seja, o que se perde é a "figura singular", a "aparição única". ${ }^{62} \mathrm{Na}$ ficção machadiana, a moda é tematizada de modo a criar uma espécie de cisão entre forma e "existência natural”, abstração que só é possível "através da propriedade particular de multiplicar-se que as formas têm”. ${ }^{63}$

\section{A felicidade e um par de botas}

"Capítulo dos chapéus" não é o único conto de Machado que se interroga sobre a moda em termos metafísicos. Em "Último capítulo", Machado investiga a moda por meio da chave da felicidade, mas não sem ironia. $\mathrm{O}$ conto consiste na justificativa do testamento de Matias Deodato de Castro e Melo, “caipora” confesso que está à beira do suicídio. Porém, nos últimos momentos de sua vida, o personagem assiste a uma cena que, se não muda o rumo de seu destino, altera os beneficiários de sua herança: ele vê "passar um 
homem bem trajado, fitando a miúdo os pés. Conhecia-o de vista; era uma vítima de grandes revezes, mas ia risonho, e contemplava os pés, digo mal, os sapatos". A cena gera a curiosa interrogação de Matias: "A felicidade será um par de botas?". Sim, responde, "a felicidade é um par de botas", e é por isso que o protagonista, em seu último ato de filantropia, decide distribuir "sapatos e botas novas" por meio de seu testamento, embora não desista de tirar a própria vida. ${ }^{64}$

Como é comum nas conclusôes machadianas, a solução é aberta, ambígua. Inclusive o próprio Matias prevê que os superficiais discordarão dele, dirão que ele está doido, e por isso ele alerta que fala "para os sapientes e para os malfadados". O que importa é que Machado expóe com perspicácia o movimento do desejo que envolve a relaçáo entre o homem e a moda, fazendo de tal desejo uma espécie de "esfera na qual elementos corpóreos e psíquicos se misturam", e dando a ele uma certa "fulguração espiritual". ${ }^{65}$ De resto, diferente de Matias, que permanece imóvel olhando o outro da janela, o outro personagem caminha, como se estivesse em um desfile de modas, ou um saláo de poses, e nisso consiste a diferença fundamental entre ambos: o personagem "levantava os olhos para as janelas, para as pessoas, mas tornava-os aos sapatos", e depois "Ele fita-as [as botas], ele respira-as, ele reluz com elas, ele calca com elas o chão de um globo que lhe pertence. Daí o orgulho das atitudes, a rigidez dos passos, e um certo ar de tranquilidade olímpica..."66

\section{Referências}

ANDRADE, Ana Luiza. Transportes pelo olhar de Machado de Assis. Chapecó: Grifos, 1999.

ASSIS, Machado de. Obra Completa. Rio de Janeiro: Nova Aguilar, 2008. 4v.

AVELAR, Idelber. "Entre o violoncelo e o cavaquinho: música e sujeito popular em Machado de Assis". Estudos de literatura brasileira contemporânea. Brasília, n. 37, p. 171-188, 2011.

BALZAC, Honoré de. Tratados da vida moderna. Trad. Leila de Aguiar Costa. São Paulo: Estação Liberdade, 2009.

BARTHES, Roland. "História e sociologia do vestuário". In: Imagem $e$ moda. Trad. Ivone Castilho Benedetti. São Paulo: Martins Fontes, 2005.

BENJAMIN, Walter. "A obra de arte na era de sua reprodutibilidade técnica”. In: . Magia e técnica, arte e política: ensaios sobre literatura e história da cultura.

Trad. Sergio Paulo Rouanet. São Paulo: Brasiliense, 1994.
64 ASSIS, Machado de. "Último capítulo", 2008, p. 362-363.

65 COCCIA, Emanuele. A vida sensivel, 2010, p. 82.

66 ASSIS, Machado de. "Último capítulo", 2008, p. 363. 
CARVAlHO, Flávio de. A moda e o novo homem. Rio de Janeiro: Azougue Editorial, 2010.

COCCIA, Emanuele. A vida sensivel. Trad. Diego Cervelin. Desterro: Cultura e Barbárie, 2010.

GROYS, Boris. Du nouveau: essai d'économie culturelle. Nîmes: Jacqueline Chambon, 1995.

MORETTI, Franco. "Homo Palpitans: os romances de Balzac e a personalidade urbana". In: Signos e estilos da modernidade: ensaio sobre a sociologia das formas literárias. Trad. Maria Beatriz de Medina. Rio de Janeiro: Civilização Brasileira, 2007.

SCHWARZ, Roberto. Um mestre na periferia do capitalismo: Machado de Assis. São Paulo: Livraria Duas Cidades, 1990.

WISNIK, José Miguel. Machado maxixe: o caso Pestana. São Paulo: PubliFolha, 2008. 